\title{
T-Cell Rich B-Cell Lymphoma- A diagnostic dilemma in paediatric oncology
}

\author{
Bhattacharya $\mathbf{A}^{1}$, Latha M. S $\mathbf{2}^{2}$, Julius X. Scott ${ }^{3}$ \\ ${ }^{1}$ Dr. Adhiraj Bhattacharya, Intern, ${ }^{2}$ Dr. Latha M. Sneha, Assistant Professor, ${ }^{3}$ Dr. Julius X. Scott, Professor of \\ Paediatrics and Head of Division of Paediatric Hematology and Oncology, all authors are affiliated with \\ Division of Pediatric Hemato Oncology, Department of Paediatrics, Sri Ramachandra Medical College \& \\ Research Institute, No.1, Ramachandra Nagar, Porur, Chennai, India.
}

Address for Correspondence: Dr. Latha M. S., Assistant Professor, Division of Pediatric Hematology \& Oncology, Department of Pediatrics, Sri Ramachandra Medical Centre, No.1, Ramachandra Nagar, Porur, Chennai, India, E-mail: drmslatha@yahoo.com

\begin{abstract}
T-cell rich B-cell lymphoma, most commonly seen in adults and rarely reported in children is a type of Diffuse Large B cell Lymphoma. (DLBCL). It has several clinical, histological and immunohistochemical similarities to commonly Nodular lymphocyte predominant Hodgkin's lymphoma. We report an 8 year-old boy who presented with a swelling over the right inguinal region for two months. FNAC of the swelling was inconclusive. MRI abdomen revealed multiple masses in right iliac fossa. Immunohistochemistry of the biopsy mass was consistent with $\mathrm{T}$ cell rich $\mathrm{B}$ cell lymphoma. T cell rich B cell lymphoma has a very low incidence in pediatric population and still remains unrecognized in most of the cases. When compared to adults, children have a better prognosis and hence stronger emphasis on immunohistochemistry is essential. Careful attention should be paid to differentiate the different neoplasms as each have a distinct course of clinical history and different therapies.
\end{abstract}

Keywords: T-cell rich B-cell lymphoma, Child, Hodgkin's lymphoma, Immunohistochemistry

\section{Introduction}

T-cell rich B-cell lymphoma (TRBCL) is considered a rare variant of aggressive B-cell lymphoma described by few neoplastic B-cells in a background of numerous benign $\mathrm{T}$ lymphocytes and histiocytes[1]. Not widely recognized in pediatric population, due to its extensive infiltrate of reactive $\mathrm{T}$ cells, causing diagnostic dilemmas, only few cases are reported. Often misdiagnosed as classical Hodgkin lymphoma or nodular lymphocyte predominant Hodgkin lymphoma or reactive lymphadenopathies, this entity should be recognized in pediatric age group, as a less aggressive treatment results in relapses. When diagnosed accurately, children respond well to chemotherapy and exhibit good prognosis. We report a case of an 8 year old boy presenting with an inguinal swelling and abdominal mass which was initially thought to be Nodular lymphocyte predominant Hodgkins lymphoma and later confirmed by IHC as T cell rich B cell lymphoma, treated as per LMB 96 protocol and is in remission now for 4 years.

\section{Case Report}

An 8 year old boy presented with a swellingover the right inguinal region for a period of two months. The swelling was slowly progressive with an increase in the size of the lesion over last two weeks. There was no history of trauma, fever loss of appetite, weight loss, or night sweats. There was also no contact history of tuberculosis. On examination there was no generalized lymphadenopathy or hepatosplenomegaly. A 1 x $2 \mathrm{cms}$

Manuscript received: $10^{\text {th }}$ September 2017

Reviewed: $18^{\text {th }}$ September 2017

Author Corrected: $25^{\text {th }}$ September 2017

Accepted for Publication: 30 $0^{\text {th }}$ September 2017 
mass could be felt over the right inguinal region. It was non tender, not fixed to skin, and firm in consistency. Genital examination was normal. Baseline investigations including complete blood counts, renal and liver function tests, AFP levels, HCG levels and serum uric acid were normal. Serum LDH was elevated (980 units IU/L). Urine VMA was normal. FNAC of swelling was suggestive of reactive lymphocytosis. MRI abdomen showed extensivepara-aortic, pre-caval, retro-caval and peri-pancreatic lymphadenopathy. Multiple soft tissue masses wereseen in the right iliac fossa, also extending into the right side of the pelvis, engulfing the iliac vessels.

He underwent laparotomy and excision biopsy of the iliac mass, whichwas provisionally reported as Hodgkin's lymphoma-Nodular lymphocyte predominant type. By immunohistochemistry the atypical cells were immune positive for CD20 and PAX-5, negative for CD30, CD15, ALK-1 and LMP, while the background cells were positive for CD3 and CD68, making it most consistent with $\mathrm{T}$ cell rich $\mathrm{B}$ cell lymphoma. Bone marrow examination and CSF analysis was normal. The patient was started on chemotherapy as per LMB 96 (Group B) protocol and PET CT after 4 cycles of chemotherapy showed complete resolution. He completed6cycles andis diseasefree for 4 years.

\section{Discussion}

Originally,T-cell-rich B-cell lymphoma (TCRBCL) was introduced to describe several variants of Bcell lymphomas with a pronounced T-cell reaction mimicking T-cell lymphoma [2]. The presence of less than $10 \%$ (sometime as low as $1 \%$ ) of usually large, neoplastic B cells in a background of numerous $\mathrm{T}$ cells was the unifying feature of the diagnosis. It was originally described as T-cell-rich B-cell lymphomain 1988 by Ramsay et al who reported five cases that had previously been misdiagnosed as peripheral T-cell lymphoma because of the presence of several T-cells surrounding a few large B cells [2].

Later in 1992 the definition was revised by Delabie et alwho introduced the term histiocyte-rich B-cell lymphoma in characterizing six cases of large Bcell lymphoma identified by minimal neoplastic B cells amidst a large population of histiocytes and small lymphocytes [3]. In 2001, the World Health Organization formally defined TCRBCL as a morphologic variant of DLBCL characterized by fewer than 10\% large neoplastic B cells amid a prominent inflammatory infiltrate, the majority of which are small polyclonal $\mathrm{T}$ cells, with or without the presence of histiocytes [4]. In 2000, aChildren's Cancer Group study reported that out of a total of 86 studied cases, $30 \%$ were diagnosed to have DLBCL. Furthermore, only of 6 cases out of these were found to have TCRBCL.

The common age group affected was between the ages of 12-16 [5]. TCRBCL can be similar to other peripheral B cell lymphoid neoplasms, most commonly nodular lymphocyte predominant
Hodgkin's lymphoma (NLPHL) making its diagnosis pathologically more challenging and thus may attribute to the low yield in the above mentioned study. The main histopathological differential diagnoses for TCRBCL are Lymphocyte rich classical HL (cHL) and Nodular lymphocytic predominant Hodgkin's lymphoma (NLPHL).

Classical Hodgkin's Lymphoma (cHL) can be mistaken for TCRBCL due to similar features of scanty neoplastic cells and abundant host inflammatory response that is further complicated by the occasional presence of HRS (Hodgkin \& Reed-Sternberg) - like neoplastic cells [6]. The majority of HRS cells are negative for CD45, CD20, and CD79a and positive for CD15 and CD30 [7].

The reactive cells in cHL include a high number of small B cells along with other inflammatory cells, including eosinophils, neutrophils, and plasma cells. The absence of this inflammatory milieu differentiates TCRBCL from classical Hodgkins Lymphoma [8].

NLPHL and TCRBCL can be immuno phenotypically similar with tumour cells that are positive for CD20 and CD79a in both. It is the presence of reactive $\mathrm{CD} 3+\mathrm{T}$ cells in the background that differentiates both entities. In addition, the back ground in NLPHL has CD57+ rosettes and $\mathrm{CD} 21+$ follicular dendritic cells, while TCRBCL shows CD68+ macrophages [9]. In our case, the HPE reports showed atypical reactive 
lymphoid cells that stained positive for CD20, CD79 and CD68 making this a diagnosis that leaned more towards TCRBCL.

B symptoms, extra nodal involvement and advanced stage disease are commonly seen in TLCBCL, unlike in other types of DLBCL.

NLPHL usually present with isolated cervical or inguinal lymphadenopathy and are at lower stage at the time of diagnosis [10]. The child in our case presented with a inguinal lymphadenopathy but constitutional and B symptoms were absent.

TCRBCL is treated like DLBCL through R-CHOP chemotherapy and children had better prognosis when compared to adults. Tiemann et al has reported an event free survival of $86 \%$ and overall survival of $94 \%$ ata median follow up of 23 months [11]. Those who were misdiagnosed and treated less aggressively had poor prognosis as they relapsed and had poor response to salvage therapies thereby highlighting the importance of accurate diagnosis at presentation [12].

\section{Conclusion}

Careful immunohistochemical analysis of both tumour cells and inflammatory micro environment is essential for accurate diagnosis of $\mathrm{T}$ cell rich $\mathrm{B}$ cell Lymphoma in children and adolescents as Hodgkin lymphoma is also of higher incidence among these age groups and the histological similarities of these two entities adds to the diagnostic dilemma. This case study highlights the difficulties in defining the specific subtypes of DLBCL and the importance of immunophenotying in accurate diagnosis of such cases.

Funding: Nil, Conflict of interest: None initiated, Perission from IRB: Yes

\section{References}

1. Lim MS, Beaty M, Sorbara L, Cheng RZ, Pittaluga S, Raffeld M, Jaffe ES. T-cell/histiocyterich large B-cell lymphoma: a heterogeneous entity with derivation from germinal center B cells. Am J Surg Pathol.2002 Nov;26(11):1458-66.

2. Ramsay AD, Smith WJ, Isaacson PG. T-cell-rich B-cell lymphoma. Am J Surg Pathol. 1988 Jun;12 (6): 433-43.
3. Delabie J, Vandenberghe E, Kennes C, Verhoef G, Foschini MP, Stul M, Cassiman JJ, De WolfPeeters C. Histiocyte- rich B-cell lymphoma. A distinct clinico pathologicentitypossibly related to lympho cytepredominant Hodgkin's disease, paragranulomasubtype. Am J Surg Pathol. 1992 Jan;16 (1): $37-48$.

4. Gatter KC, Warnke RA, Macon WR, McCurley TL. Diffuse large B-cell lymphoma. In: Jaffe ES, Harris NL, Stein H, Vardiman JW, eds. WHO Classification of Tumours: Pathology and Genetics of Tumours of Haematopoietic and Lymphoid Tissues. Lyon, France : IARC Press; 2001: $171-76$.

5. Lones MA, Cairo MS, Perkins SL. T-cell-rich large B-cell lymphoma in children and adolescents: a clinicopathologic report of six cases from the Children's Cancer Group Study CCG-5961. Cancer. 2000;88 (10): 2378-86.

6. Abramson JS. T-cell/ histiocyte- rich B-cell lymphoma: biology, diagnosis, and management. Oncologist. 2006 Apr; 11 (4) : 384-92.

7. Fraga M, Sanchez-Verde L, Forteza J et al. Tcell/histiocyte-rich large B- cell lymphoma is a disseminated aggressive neoplasm: differential diagnosis from Hodgkin's lymphoma. Histopathology. 2002; 41 (3): 216-29. DOI: 10. 1046/j. 1365 - 2559. 2002.01466.x

8. Gabriela G, Hemalatha G R, Bruce C, Annette S, Steven $\mathrm{K}$ et al. T-cell /Histiocyte- Rich Large Bcell Lymphoma in Pediatric Patients: an UnderRecognized Entity?. Annals of Clinical \& Laboratory Science. 2015:45(1)73-8.

9. Stein H, Delsol G, Pileri A et al. Nodular lymphocyte predominant Hodgkin lymphoma. In: Jaffe ES, Harris NL, Stein H et al., eds. Tumours of Haematopoietic and Lymphoid Tissues. Lyon: IARC Press, 2001:240-43.

10. Weshi A, Akhtar S, Mourad WA, et al. Tcell/histiocyte-rich B-cell lymphoma: Clinical presentation, management and prognostic factors: report on 61 patients and review of literature. Leuk Lymphoma. 2007;48:1764-73.http://dx.doi.org/10. $1080 / 10428190701559124$ 


\section{Case Report}

11. Tiemann M, Rienner MO, Claviez A et al. Proliferation rate and outcome in children with $\mathrm{T}$ cell rich B cell Lymphoma: a clinicopathologic study from the NHL-BFM study group. Leuk Lymphoma.2005;46(9):1295-300.http://dx.doi. org/ 10. $1080 / 10428190500083326$
12. Mc Bride JA, Rodriguez J, Luthra R, et al. Tcell - rich B largecell lymphoma simulating lymphocyte- rich Hodgkin's disease. Am J Surg Pathol. 1996;20(2):193-201.

\section{How to cite this article?}

Bhattacharya A, Latha M. S, Julius X. Scott. T-Cell Rich B-Cell Lymphoma- A diagnostic dilemma in paediatric oncology. J PediatrRes. 2017;4(09):584-587.doi:10. 17511/ijpr.2017.i09.08. 